\title{
Enterprise Architecture Sebagai Optimalisasi Proses Dan Pengembangan Teknologi Informasi Menggunakan Togaf ADM (Studi Kasus: PT XYZ)
}

\author{
Robi Dewi Asih Pramesti*1, Asti Amalia Nur Fajrillah ${ }^{2}$, Widyatasya Agustika Nurtrisha ${ }^{3}$ \\ ${ }^{1,2,3}$ Prodi S1 Sistem Informasi, Fakultas Rekayasa Industri, Universitas Telkom, Bandung \\ e-mail:*11 robidewiasih@student.telkomuniversity.ac.id, ${ }^{2}$ astiamalia@telkomuniversity.ac.id, \\ ${ }^{3}$ widyatasya@telkomuniveristy.ac.id
}

\begin{abstract}
Abstrak
Teknologi Informasi memiliki peran penting bagi perusahaan dalam mengolah dan menyediakan informasi yang dibutuhkan oleh para stakeholder. Namun, tidak semua perusahaan mampu mengimplementasikan dan mengembangkan teknologi informasi yang bersesuaian dengan kebutuhan perusahaan, termasuk PT XYZ. PT XYZ merupakan perusahaan jasa yang bergerak dibidang sertifikasi Verifikasi Legalitas Kayu (VLK). Dalam menjalankan perusahaannya, PT XYZ didukung oleh fungsi Manajemen Umum dan Keuangan. Namun seiring berjalannya waktu, fungsi Manajemen Umum dan Keuangan tidak dapat menyesuaikan dengan cepat perkembangan teknologi yang ada. Hal ini ditandai dengan terbatasnya sistem yang digunakan oleh perusahaan seperti Microsoft Excel. Penggunaan TI yang belum optimal berdampak pada internal dan eksternal perusahaan, yang menyebabkan terjadinya penurunan tingkat loyalitas pelanggan sebesar 46,43\% selama setahun terakhir. Untuk itu diperlukan solusi Enterprise Architecture (EA) guna menyelaraskan kebutuhan bisnis dan teknologi, juga mengoptimalisasi pengembangan teknologi informasi. Enterprise architecture dirancang menggunakan metode TOGAF ADM. Perancangan EA dimulai dari Preliminary Phase sampai Information System Architecture (Application Architecture). Penelitian ini akan menghasilkan artefak berupa matrices, catalog, dan diagram. Adapun hasil akhir penelitian ini adalah rancangan Blueprint Enterprise Architecture sebagai gambaran umum usulan proyek untuk mendukung strategi bisnis dan pengembangan teknologi pada fungsi Manajemen Umum dan Keuangan di PT XYZ.
\end{abstract}

Kata kunci-Blueprint, Enterprise Architecture, Manajemen Umum dan Keuangan, Teknologi Informasi (TI); TOGAF ADM.

\begin{abstract}
Information Technology has an important role for companies in processing and providing the information needed by stakeholders. However, not all companies can implement and develop information technology following the company's needs, including Certification Service Companies. Certification Service Company is a service company engaged in Timber Legality Verification (VLK) certification. In running the company, the Certification Services Company supports by the General Management and Finance functions. But as time goes by, General Management and Finance functions were unable to adapt quickly to the development of existing technology. That is marks by the limited system used by companies such as Microsoft Excel. The use of IT that has not been optimal has an impact on the company's internal and external, which causes a decrease in the level of customer loyalty by $46.43 \%$ over the past year. For this, an Enterprise Architecture (EA) solution needs to align business and technology needs and optimize the development of information technology. Enterprise architecture was design using the TOGAF ADM method. EA design starts from Preliminary Phase to Information
\end{abstract}


System Architecture (Application Architecture). This research will produce artifacts in the form of matrices, catalogs, and diagrams. The result of this research is a Blueprint Enterprise Architecture design as an overview of project proposals to support business strategies and technologies improvement in the General and Financial Management functions in PT XYZ.

Keywords-Blueprint, Enterprise Architecture, General Management and Finance Function, Information Technology (IT), TOGAF ADM.

\section{PENDAHULUAN}

$P^{a}$ ada era modern saat ini, perkembangan teknologi informasi dimanfaatkan oleh manusia untuk menyelesaikan semua pekerjaan dan segala aspek kehidupan yang ditandai oleh berkembangnya Teknologi Informasi (TI). Selain berdampak pada segala aspek kehidupan manusia, perkembangan teknologi informasi juga berdampak pada perilaku perusahaan dalam melakukan peta persaingan [1]. Dalam penerapannya, teknologi informasi ini juga memiliki peran penting bagi perusahaan dalam mewujudkan kinerja yang lebih cepat, akurat, transparan serta handal dalam mengolah dan menyediakan informasi - informasi yang dibutuhkan oleh para stakeholder [2]. Teknologi Informasi yang tepat dapat mewujudkan organisasi yang efektif dan efisien jika keselarasan strategi TI dan strategi bisnis diutamakan [3]. Namun, tidak semua perusahaan mampu mengimplementasikan dan mengembangkan teknologi informasi yang bersesuaian dengan kebutuhan perusahaan. Salah satunya yaitu PT XYZ.

PT XYZ merupakan perusahaan jasa yang bergerak dibidang standar Verifikasi Legalitas Kayu (VLK) untuk menjamin bahwa produksi kayu yang dihasilkan adalah legal dan bersumber dari hasil hutan yang legal. PT XYZ memiliki 6 fungsi dalam menjalankan kegiatan bisnisnya yaitu fungsi Sertifikasi, fungsi Tata Kelola Kebijakan, fungsi Manajemen Umum dan Keuangan, fungsi Service, fungsi Pengelolaan Teknologi, dan fungsi Sumber Daya Manusia (SDM). Salah satu fungsi PT XYZ yang diambil sebagai topik penelitian kali ini adalah fungsi Manajemen Umum dan Keuangan. Fungsi Manajemen Umum dan Keuangan merupakan fungsi pendukung yang bertanggung jawab dalam mengelola dan menyimpan segala berkas, memanajemen keuangan, dan memasarkan layanan yang dibutuhkan untuk mencapai tujuan perusahaan. Selain itu, fungsi Manajemen Umum dan Keuangan juga bertanggung jawab dalam menyediakan informasi yang dapat diakses oleh fungsi lain yang membutuhkan, sebagai contoh yaitu auditor yang membutuhkan data pada saat turun ke lapangan.

Seiring berjalannya waktu, fungsi Manajemen Umum dan Keuangan tidak dapat menyesuaikan dengan cepat perkembangan teknologi yang ada. Hal ini ditandai dengan tidak maksimalnya respon yang diberikan oleh fungsi Manajemen Umum dan Keuangan kepada Unit Bisnis terkait khususnya fungsi Sertifikasi, dimana fungsi Sertifikasi merupakan fungsi utama dalam kegiatan operasional bisnis perusahaan. Respon yang tidak maksimal dipengaruhi oleh penggunaan sistem yang belum terintegrasi dengan baik, pengelolaan database yang tidak terpusat, dan penggunaan aplikasi yang implementasinya belum sesuai dengan kebutuhan perusahaan maupun meningkatkan operasional bisnis perusahaan. Penggunaan teknologi informasi yang belum maksimal, bisa merugikan perusahaan seperti tidak sesuai dengan keinginan pasar, kehilangan loyalitas pelanggan, maupun kehilangan karyawan yang kompeten [4].

Salah satu sistem yang digunakan adalah Microsoft Office. Terbatasnya sistem dalam Microsoft Office menyebabkan belum terintegrasinya data antara fungsi sertifikasi dengan fungsi Manajemen Umum dan Keuangan berupa data hasil sertifikasi oleh auditor pada saat dilapangan tidak ter-update secara real time dengan database yang dimiliki kantor pusat serta

Pramesti, ei., al [Enterprise Architecture Sebagai Optimalisasi Proses dan Pengembangan Teknologi Informasi Menggunakan Togaf ADM (Studi Kasus: PT XYZ) 
belum tersinkronisasinya antara data penerbitan v-legal dengan penagihannya. Selain berdampak pada internal perusahaan, kendala tersebut juga menimbulkan keluhan bagi pelanggan yang menyebabkan terjadinya penurunan tingkat loyalitas pelanggan sebesar 46,43\% selama setahun terakhir. Hal ini dibuktikan berdasarkan hasil wawancara kepada pihak perusahaan yang menyatakan bahwa terdapat keluhan langsung oleh klien mengenai pelayanan proses sertifikasi. Atas permasalahan yang terjadi, tentunya tidak selaras dengan visi PT XYZ yaitu menjadi lembaga sertifikasi yang handal, professional, bertanggung jawab, dan memberikan hasil berdaya guna dengan mengutamakan kepuasan pelanggan. Untuk itu diperlukan optimalisasi implementasi dari pengembangan aplikasi ataupun penyelaraskan kebutuhan bisnis dan teknologi melalui perencanaan yang baik. Salah satu perencanaan tersebut bisa menggunakan Enterprise Architecture (EA).

Menurut [5], Enterprise Architecture berisi deskripsi formal mengenai keadaan perusahaan saat ini dan dimasa yang akan datang diikuti perubahan terkelola untuk mencapai tujuan pemangku kepentingan dan memberikan nilai bagi perusahaan. Implementasi EA yang penting adalah menganalisis as-is dan menentukan to-be yang diharapkan dan memastikan bahwa realisasi pengembangan berada pada jalur yang tepat untuk mencapai tujuan yang diharapkan [6]. Ada beberapa keuntungan yang didapatkan perusahaan dengan membangun EA yang baik yaitu, operasi teknologi informasi dan bisnis menjadi lebih cepat, sederhana, dan efisien dan meminimalisir resiko yang muncul [7].

Berdasarkan kondisi dan fakta mendukung diatas, untuk memaksimalkan penerapan EA, dibutuhkan sebuah framework yang memiliki model simbolis untuk dapat mendetailkan berbagai fase EA lebih dalam [8]. Penulis mengajukan penggunaan framework TOGAF (The Open Group Architecture Framework) karena dalam kenyataanya TOGAF sudah banyak diadopsi oleh banyak organisasi karena memiliki beberapa keunggulan terutama proses arsitekturnya yang matang [9]. Metode yang digunakan adalah TOGAF ADM dalam perancangan enterprise architecture sebagai solusi untuk mengatasi permasalahan yang ada di fungsi Manajemen Umum dan Keuangan. Perancangan EA dimulai dari Preliminary Phase sampai Information System Architecture (Application Architecture) yang akan menghasilkan artefak berupa matrices, catalog, dan diagram. Adapun hasil akhir penelitian ini adalah rancangan Blueprint Enterprise Architecture sebagai gambaran umum usulan proyek untuk mendukung strategi bisnis dan pengembangan teknologi pada fungsi Manajemen Umum dan Keuangan di PT XYZ.

\section{METODE PENELITIAN}

Metode penelitian merupakan suatu cara ilmiah dalam mengumpulkan data dan informasi yang valid dengan tujuan dapat ditemukan, dibuktikan, maupun dikembangkan untuk dapat dipahami, dipecahkan, dan menjadi solusi atas suatu permasalahan [10]. Dalam penelitian ini, metode penelitian digunakan untuk menentukan langkah-langkah yang dilakukan dalam mengolah informasi dan mengolah hasil investigasi terhadap objek penelitian. Metode penelitian digambarkan oleh sebuah kerangka tahapan bagaimana informasi dan hasil investigasi diperoleh dan dikumpulkan serta prosedur dan langkah-langkah yang harus ditempuh.

Pengumpulan data dilakukan melalui studi literatur dan studi lapangan. Studi literatur dilakukan dengan cara membaca dan menganalisis jurnal, penelitian sebelumnya, website yang berkaitan dengan perusahaan dan SOP (Standard Operational Procedure) yang dimiliki perusahaan. Sedangkan untuk studi lapangan dilakukan dengan wawancara ke pihak perusahaan untuk memvalidasi hasil studi literatur. 
Setelah data dan informasi dikumpulkan, langkah selanjutnya adalah pemetaan data dan informasi tersebut kedalam metodologi dan tahapan-tahapan perancangan EA yang telah tersedia pada framework TOGAF ADM. Untuk pemetaan kedalam TOGAF ADM, dapat dilihat pada Tabel 1 sebagai berikut.

Tabel 1. Pemetaan Metodologi TOGAF ADM

\begin{tabular}{|c|c|c|c|}
\hline Fase & Input & Proses & Output \\
\hline $\begin{array}{l}\text { Preliminary } \\
\text { Phase }\end{array}$ & $\begin{array}{l}\text { 1. Profil Perusahaan } \\
\text { 2. Standard } \\
\text { Operational } \\
\text { Procedure (SOP) } \\
\text { 3. Hasil wawancara }\end{array}$ & $\begin{array}{l}\text { 1. Identifikasi } \\
\text { Enterprise } \\
\text { 2. Identifikasi } \\
\text { Menyusun } \\
\text { Arsitektur } \\
\text { 3. Identifikasi Brinsip } \\
\text { Goals, Drivers, dan } \\
\text { Constraint } \\
\end{array}$ & $\begin{array}{l}\text { 1. Principle } \\
\text { Catalog }\end{array}$ \\
\hline $\begin{array}{l}\text { Phase A: } \\
\text { Architecture } \\
\text { Vision }\end{array}$ & $\begin{array}{l}\text { 1. Standard } \\
\text { Operational } \\
\text { Procedure (SOP) } \\
\text { 2. Hasil wawancara }\end{array}$ & $\begin{array}{l}\text { 1. Identifikasi } \\
\text { Stekeholders, Fokus, dan } \\
\text { Requirement Business } \\
\text { 2. Evaluasi Business } \\
\text { Capabilities } \\
\text { 3. Identifikasi Target } \\
\text { Architecture, Value } \\
\text { Proposition, dan KPI }\end{array}$ & $\begin{array}{l}\text { 1. Value Chain } \\
\text { Diagram } \\
\text { 2. Solution } \\
\text { Concept } \\
\text { Diagram }\end{array}$ \\
\hline $\begin{array}{l}\text { Phase B: } \\
\text { Business } \\
\text { Architecture }\end{array}$ & $\begin{array}{l}\text { 1. SOP PT Mandiri } \\
\text { Mutu Sertifikasi } \\
\text { 2. Kondisi Eksisting } \\
\text { Bisnis pada Fungsi } \\
\text { Manajemen Umum } \\
\text { dan Keuangan } \\
\text { 3. Hasil wawancara } \\
\end{array}$ & $\begin{array}{l}\text { 1. Identifikasi Kondisi } \\
\text { Baseline Business } \\
\text { Architecture } \\
\text { 2. Perencanaan Targeting } \\
\text { Business Architecture } \\
\text { 3. Menyusun GAP Analysis } \\
\text { Business Architecture } \\
\end{array}$ & $\begin{array}{l}\text { 1. Organizational } \\
\text { Process Target } \\
\text { Diagram } \\
\text { 2. GAP Analysis } \\
\text { Business } \\
\text { Architecture }\end{array}$ \\
\hline $\begin{array}{l}\text { Phase C: } \\
\text { Information } \\
\text { System } \\
\text { Architecture } \\
\text { (Data } \\
\text { Architecture) }\end{array}$ & $\begin{array}{l}\text { 1. Kondisi Eksisting } \\
\text { Data pada Fungsi } \\
\text { Manajemen Umum } \\
\text { dan Keuangan } \\
\text { 2. Kondisi Eksisting } \\
\text { Aplikasi r pada } \\
\text { Fungsi Manajemen } \\
\text { Umum r dan } \\
\text { Keuangan } \\
\end{array}$ & $\begin{array}{lr}\text { 1. Identifikasi } & \text { Catalog, } \\
\text { Matrix, dan } & \text { Diagram } \\
\text { yang dibutuhkan } & \\
\text { 2. Identifikasi } & \text { kondisi } \\
\text { Baseline } & \text { Data } \\
\text { Architecture } & \end{array}$ & $\begin{array}{l}\text { 1. Data } \\
\text { Entity/Business } \\
\text { Function } \\
\text { Matrix } \\
\text { 2. Conceptual } \\
\text { Data Diagram }\end{array}$ \\
\hline
\end{tabular}




\begin{tabular}{|c|c|c|c|}
\hline $\begin{array}{l}\text { Phase C: } \\
\text { Information } \\
\text { System } \\
\text { Architecture } \\
\text { (Application } \\
\text { Architecture) }\end{array}$ & $\begin{array}{lr}\text { 1. Kondisi } & \text { Eksisting } \\
\text { Aplikasi } & \text { pada } \\
\text { Fungsi } & \text { Manajemen } \\
\text { Umum r } & \text { dan } \\
\text { Keuangan } & \end{array}$ & $\begin{array}{l}\text { 1. Identifikasi Catalog, } \\
\text { Matrix, dan Diagram } \\
\text { yang dibutuhkan } \\
\text { 2. Identifikasi kondisi } \\
\text { Baseline Application } \\
\text { Architecture } \\
\text { 3. Perencanaan Targeting } \\
\text { Application Architecture } \\
\text { 4. Menyusun GAP Analysis } \\
\text { Application Architecture }\end{array}$ & $\begin{array}{l}\text { 1. Application/Fu } \\
\text { nction Matrix } \\
\text { 2. Application } \\
\text { Comunication } \\
\text { Diagram }\end{array}$ \\
\hline
\end{tabular}

Berdasarkan Tabel 1. diatas, berikut akan dijelaskan penjabaran aktivitas yang dilakukan untuk melakukan pemetaan metodologi TOGAF ADM:

\subsection{Preliminary Phase}

Dalam penyusunan artefak yang ada di fase Architecture Vision, Penulis menganalisis terlebih dahulu referensi prinsip-prinsip yang disediakan TOGAF ADM 9.1. Kemudian dilanjutkan dengan menganalisis SOP yang dimiliki PT XYZ untuk mendapatkan data - data yang dibutuhkan dan terakhir melakukan validasi melalui wawancara ke perusahaan. Output yang dihasilkan berupa principle catalog yang berisi prinsip - prinsip yang telah ditetapkan untuk membangun enterprise architecture kedepannya.

\subsection{Architecture Vision}

Dalam penyusunan artefak yang ada di fase Architecture Vision, dilakukan pengumpulan data dan informasi terlebih dahulu dengan menganalisis SOP yang dimiliki PT XYZ. Setelah mendapatkan data, Penulis melakukan validasi dengan melakukan wawancara ke perusahaan. Output yang dihasilkan berupa goal catalog, goal diagram, stakeholder map matriks, value chain diagram, solution concept diagram, dan requirement catalog.

\subsection{Business Architecture}

Fase ini merupakan fase perancangan kondisi arsitektur bisnis perusahaan dan memodelkan rancangan target yang sesuai dengan Architecture Vision yang telah dibuat sebelumnya. Proses yang dilakukan untuk mendapatkan data dan informasi adalah menganalisis hubungan antara visi dan misi, KPI (Key Performance Indicator), Rencana Jangka Panjang, dan SOP milik PT XYZ agar solusi yang dibuat sejalan dengan kebutuhan dan permasalahan PT XYZ. Setelah itu untuk menjamin kesesuaian dengan kondisi nyata perusahaan, dilakukan validasi ke perusahaan melalui wawancara.

\subsection{Information System Architecture}

Fase ini terbagi menjadi dua arsitektur utama, yaitu:

\subsubsection{Data Architecture}

Sub-fase ini bertujuan untuk mendefinisikan kebutuhan data berupa tipe data dan sumber data yang dibutuhkan sebagai pendukung proses bisnis fungsi Manajemen Umum dan Keuangan. Proses yang dilakukan untuk mendapatkan data dan informasi adalah dengan melakukan analisis terhadap SOP milik PT XYZ, proses bisnis eksisting maupun target fungsi Manajemen Umum dan Keuangan, serta relasi antar aplikasi yang digunakan. Kemudian untuk 
menjamin kesesuaian dengan kondisi nyata perusahaan, dilakukan validasi ke perusahaan melalui wawancara.

\subsubsection{Appplication Architecture}

Merupakan sub-fase kedua pada Information System Architecture yang merepresentasikan blueprint dari masing-masing aplikasi yang berinteraksi dengan aplikasi lainnya yang terhubung dengan proses bisnis utama organisasi [11]. Proses pengumpulan data dilakukan dengan melakukan analisis terhadap SOP milik PT XYZ, proses bisnis eksisting maupun target, data komponen eksisting maupun target, serta aplikasi eksisting dan relasinya yang digunakan oleh PT XYZ. Kemudian untuk menjamin kesesuaian dengan kondisi nyata perusahaan, Penulis melakukan validasi ke perusahaan melalui wawancara.

\section{HASIL DAN PEMBAHASAN}

\subsection{Preliminary Phase}

Tahap persiapan untuk mendefinisikan kerangka kerja dan prinsip - prinsip yang dibutuhkan dalam merancang Enterprise Architecture. Output pada fase ini yaitu principle catalog yang berisi prinsip - prinsip dari arsitektur bisnis, data, aplikasi, dan teknologi. Untuk principle catalog, dapat dilihat pada Tabel 2 berikut ini.

Tabel 2 Principle Catalog

\begin{tabular}{|c|c|c|c|}
\hline No. & Arsitektur & Prinsip & Deskripsi \\
\hline \multirow[t]{5}{*}{1} & \multirow[t]{5}{*}{ Business } & $\begin{array}{l}\text { Information } \\
\text { Management is } \\
\text { Everybody's } \\
\text { Business }\end{array}$ & $\begin{array}{l}\text { Keterlibatan seluruh stakeholder perusahaan } \\
\text { dalam berpartisipasi untuk menghasilkan } \\
\text { keputusan manajemen informasi yang dibutuhkan } \\
\text { untuk mencapai tujuan bisnis. }\end{array}$ \\
\hline & & $\begin{array}{l}\text { Business } \\
\text { Continuity }\end{array}$ & $\begin{array}{l}\text { Operasional perusahaan terus berjalan dan diawasi } \\
\text { sebagaimana mestinya walaupun terdapat } \\
\text { gangguan sistem }\end{array}$ \\
\hline & & $\begin{array}{l}\text { Compliance } \\
\text { with Law }\end{array}$ & $\begin{array}{l}\text { Segala kegiatan operasional atau proses bisnis } \\
\text { yang dilakukan oleh PT XYZ harus sesuai dengan } \\
\text { kebijakan dan peraturan yang berlaku }\end{array}$ \\
\hline & & Kualitas layanan & $\begin{array}{l}\text { Memaksimalkan kualitas layanan yang disediakan } \\
\text { kepada client }\end{array}$ \\
\hline & & $\begin{array}{l}\text { SDM yang } \\
\text { Kompeten }\end{array}$ & $\begin{array}{l}\text { Mengembangkan sikap individu yang dapat } \\
\text { diandalkan dan memiliki kompetensi yang sesuai } \\
\text { dengan standar }\end{array}$ \\
\hline 2 & Data & Data is an Asset & $\begin{array}{l}\text { Data merupakan aset penting dengan value yang } \\
\text { tinggi untuk perusahaan yang harus dikelola } \\
\text { dengan tepat. }\end{array}$ \\
\hline
\end{tabular}

Pramesti, ei., al [Enterprise Architecture Sebagai Optimalisasi Proses dan Pengembangan Teknologi Informasi Menggunakan Togaf ADM (Studi Kasus: PT XYZ) 


\begin{tabular}{|c|c|c|c|}
\hline & & \multirow{2}{*}{$\begin{array}{l}\text { Data is Shared } \\
\\
\\
\begin{array}{l}\text { Data is } \\
\text { Accessible }\end{array}\end{array}$} & \multirow{2}{*}{ 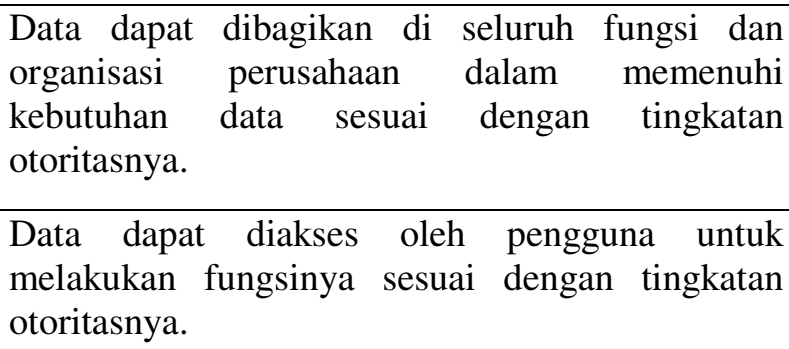 } \\
\hline & & & \\
\hline & & Data Trustee & $\begin{array}{l}\text { Setiap elemen data memiliki keamanan yang } \\
\text { bertanggung jawab atas kualitas data }\end{array}$ \\
\hline & & $\begin{array}{l}\text { Common } \\
\text { Vocabulary and } \\
\text { Data Definitions }\end{array}$ & $\begin{array}{l}\text { Data didefinisikan secara konsisten di seluruh } \\
\text { perusahaan, dan definisi tersebut dapat dipahami } \\
\text { dan tersedia untuk semua pengguna. }\end{array}$ \\
\hline & & Data Security & $\begin{array}{l}\text { Data dilindungi dari penggunaan dan } \\
\text { pengungkapan yang tidak sah. Selain aspek } \\
\text { klasifikasi keamanan, tidak terbatas pada: } \\
\text { perlindungan informasi } \\
\text { sensitivitas, dan hak milik. }\end{array}$ \\
\hline \multirow[t]{2}{*}{3} & \multirow[t]{2}{*}{ Application } & $\begin{array}{l}\text { Technology } \\
\text { Independence }\end{array}$ & $\begin{array}{l}\text { Aplikasi tidak tergantung pada pilihan teknologi } \\
\text { tertentu dan oleh karena itu dapat beroperasi pada } \\
\text { berbagai platform teknologi. }\end{array}$ \\
\hline & & Ease-of-Use & $\begin{array}{l}\text { Aplikasi mudah digunakan dan dimengerti oleh } \\
\text { pengguna }\end{array}$ \\
\hline \multirow[t]{5}{*}{4} & \multirow[t]{5}{*}{ Technology } & $\begin{array}{l}\text { Requirement } \\
\text { Based Change }\end{array}$ & $\begin{array}{l}\text { Teknologi mampu merespon perubahan sesuai } \\
\text { kebutuhan bisnis, data, dan teknologi dalam } \\
\text { menjalankan kegiatan operasionalnya. }\end{array}$ \\
\hline & & $\begin{array}{l}\text { Control } \\
\text { Technical } \\
\text { Diversity }\end{array}$ & $\begin{array}{l}\text { Teknologi yang ada pada perusahaan diawasi dan } \\
\text { dievaluasi, sebagai langkah meminimalisir biaya } \\
\text { yang dikeluarkan. }\end{array}$ \\
\hline & & Interoperability & $\begin{array}{l}\text { Teknologi yang ada harus sesuai dengan standar } \\
\text { yang ditetapkan oleh perusahaan sehingga mampu } \\
\text { mendukung integrasi antar data, aplikasi, dan } \\
\text { teknologi. }\end{array}$ \\
\hline & & $\begin{array}{l}\text { Keamanan } \\
\text { Teknologi }\end{array}$ & $\begin{array}{l}\text { Teknologi yang ada mampu melindungi seluruh } \\
\text { komponen sistem informasi yang ada pada } \\
\text { organisasi }\end{array}$ \\
\hline & & $\begin{array}{l}\text { Kehandalan } \\
\text { teknologi }\end{array}$ & $\begin{array}{l}\text { Teknologi yang ada mampu mengintegrasikan } \\
\text { sistem yang ada pada perusahaan. }\end{array}$ \\
\hline
\end{tabular}

\subsection{Architecture Vision}

Pada fase ini dilakukan dengan beberapa cara, salah duanya yaitu perancangan value chain diagram untuk menggambarkan fungsi-fungsi yang ada di PT XYZ dalam menghasilkan value perusahaan dan solution concept diagram untuk menggambarkan solusi teknologi informasi baik yang sudah digunakan maupun akan diusulkan untuk dijadikan acuan dalam 
Jatisi

ISSN 2407-4322

Vol. 8, No. 4, Desember 2021, Hal. 1945-1959

E- ISSN 2503-2933

1952

mencapai Target Architecture. Berikut dapat dilihat value chain diagram dan solution concept diagram PT XYZ pada Gambar 1 dan Gambar 2 dibawah ini.

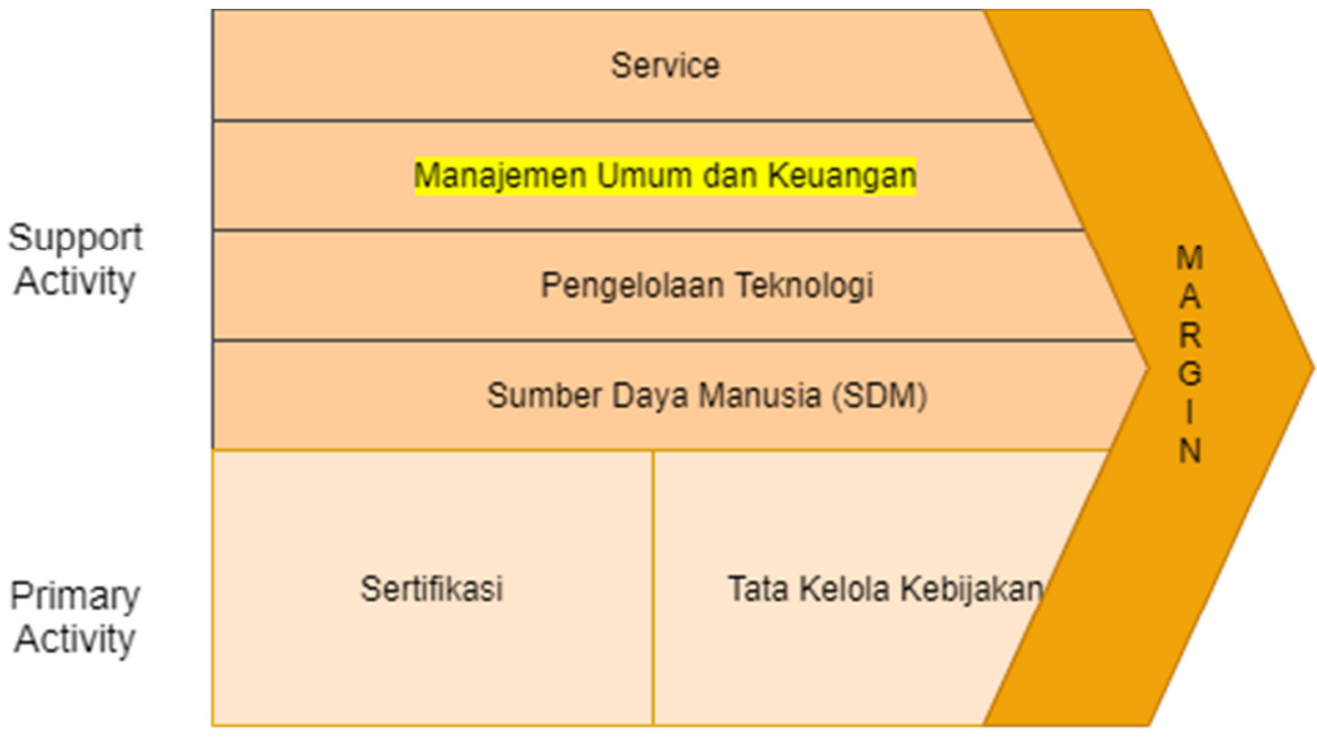

Gambar 1. Value Chain Diagram PT XYZ

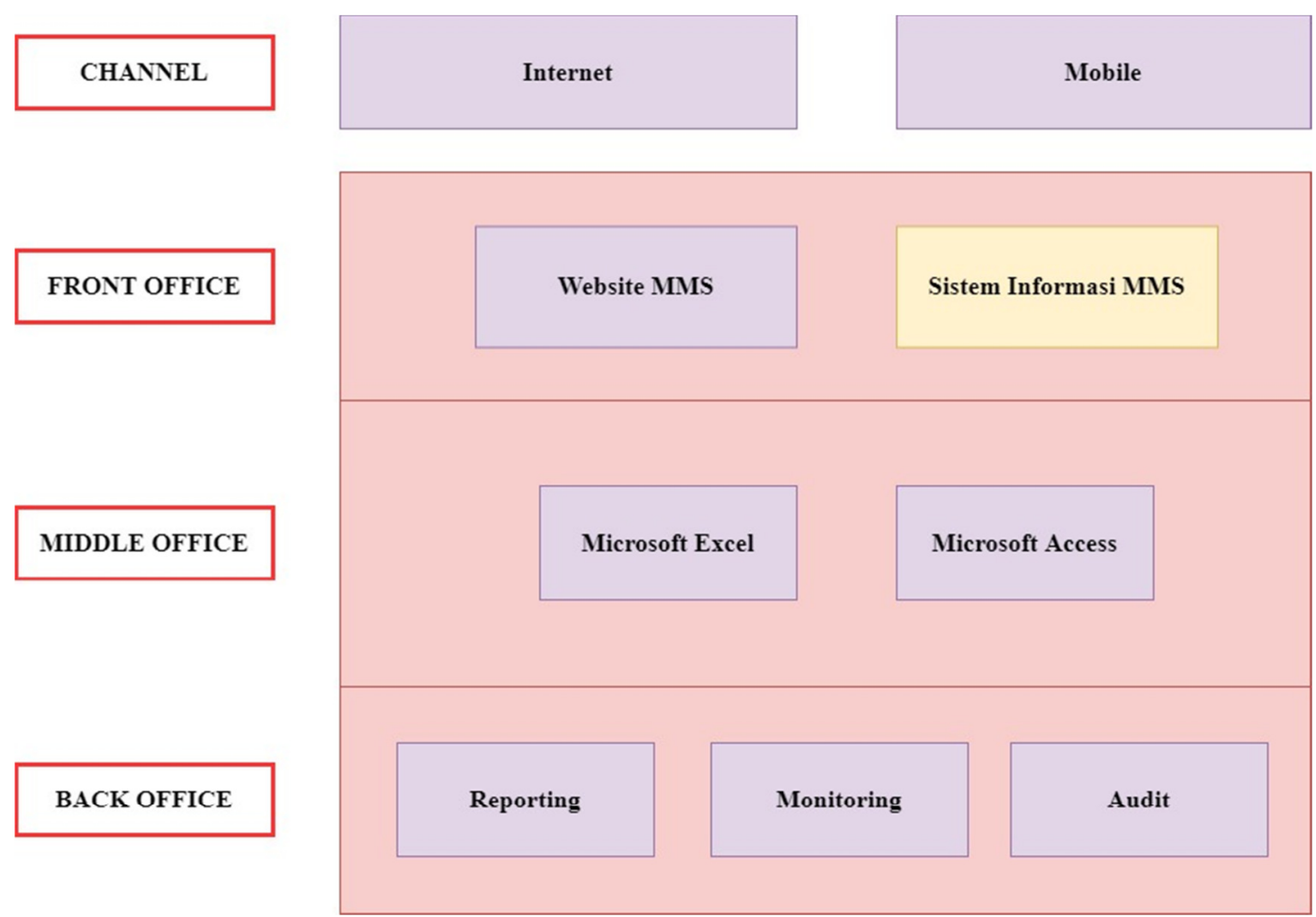

Gambar 2. Solution Concept Diagram PT XYZ

Pramesti, ei., al [Enterprise Architecture Sebagai Optimalisasi Proses dan Pengembangan Teknologi Informasi Menggunakan Togaf ADM (Studi Kasus: PT XYZ) 


\subsection{Business Architecture}

Fase ini dilakukan dengan beberapa cara yaitu perancangan proses bisnis target yang menjadi usulan untuk memperbaiki proses bisnis eksiting yang belum optimal dan GAP Analysis Business untuk memvalidasi arsitektur yang dikembangkan melalui tahap analisis requirement apa saja yang belum tercapai dan sudah tercapai.

\subsubsection{Target Arsitektur Bisnis}

Perencanaan target proses bisnis dilakukan untuk memperbaiki proses bisnis sebelumnya yang kurang optimal. Beberapa cara yang diusulkan berupa pemanfaatan teknologi informasi untuk mengintegrasikan antara satu fungsi dengan fungsi lainnya dan penambahan aktifitas baru untuk mengoptimalkan proses yang sudah ada. Target proses bisnis yang diusulkan meliputi:

a) Pengendalian Rekaman

Adanya perubahan aktivitas berupa pengumpulan dokumen oleh Divisi/Unit Bisnis dan pembuatan dokumen menjadi sebuah rekaman yang dilakukan oleh Manajer Umum dan Keuangan, diusulkan untuk dapat dilakukan melalui Sistem Informasi MMS (SIMMS). Dengan SIMMS, proses pertukaran data menjadi lebih real-time, menghindari duplikasi data, dan aktivitas yang dilakukan lebih efisien berkat integrasi data antar fungsi melalui sistem tersebut.

b) Pengelolaan Keuangan

Adanya perubahan aktivitas berupa penyesuaian data penagihan dengan dokumen sertifikasi yang digunakan dilakukan melalui Sistem Informasi MMS (SIMMS). Dimana didalam sistem tersebut, Staff Keuangan tidak perlu untuk melakukan penyortiran kesesuaian data penagihan dengan data pelunasan karena sistem yang ada dapat meminimalisir duplikasi data.

c) Pemasaran Layanan

Adanya penambahan dan pengembangan aktivitas berupa penyebarluasan media marketing dan kerjasama dengan Kementerian Kehutanan untuk mendapatkan cakupan klien yang lebih luas.

Setelah proses bisnis usulan telah dibuat, langkah selanjutnya adalah memvalidasi arsitektur yang dikembangkan melalui tahap analisis requirement untuk melihat apa yang telah tercapai dan belum tercapai. Analisis requirement tersebut dapat dilihat pada Tabel 3 GAP Analysis Business berikut ini.

Tabel 3 GAP Analysis Business

\begin{tabular}{|c|c|c|c|c|c|}
\hline $\begin{array}{l}\text { Eksisting/ } \\
\text { Targeting }\end{array}$ & $\begin{array}{l}\text { Pengelolaan } \\
\text { Informasi }\end{array}$ & $\begin{array}{c}\text { Pengendalian } \\
\text { Dokumen }\end{array}$ & $\begin{array}{l}\text { Pengendalian } \\
\text { Rekaman }\end{array}$ & $\begin{array}{c}\text { Pengelolaan } \\
\text { Keuangan }\end{array}$ & $\begin{array}{c}\text { Pemasaran } \\
\text { Layanan }\end{array}$ \\
\hline $\begin{array}{l}\text { Pengelolaan } \\
\text { Informasi }\end{array}$ & $\mathrm{R}$ & & & & \\
\hline $\begin{array}{l}\text { Pengendalian } \\
\text { Dokumen }\end{array}$ & & $\mathrm{R}$ & & & \\
\hline $\begin{array}{l}\text { Pengendalian } \\
\text { Rekaman }\end{array}$ & & & I & & \\
\hline $\begin{array}{l}\text { Pengelolaan } \\
\text { Keuangan }\end{array}$ & & & & I & \\
\hline $\begin{array}{l}\text { Pemasaran } \\
\text { Layanan }\end{array}$ & & & & & $\mathrm{I}$ \\
\hline Perubahan & - & - & $\begin{array}{l}\text { Mengembangkan } \\
\text { sistem baru dari } \\
\text { Sistem Informasi }\end{array}$ & $\begin{array}{lr}\text { Mengembang } \\
\text { kan } & \text { sistem } \\
\text { baru } & \text { dari }\end{array}$ & $\begin{array}{l}\text { Mengembangkan } \\
\text { probis dengan } \\
\text { menambahkan }\end{array}$ \\
\hline
\end{tabular}

Pramesti, ei., al [Enterprise Architecture Sebagai Optimalisasi Proses dan Pengembangan Teknologi Informasi Menggunakan Togaf ADM (Studi Kasus: PT XYZ) 


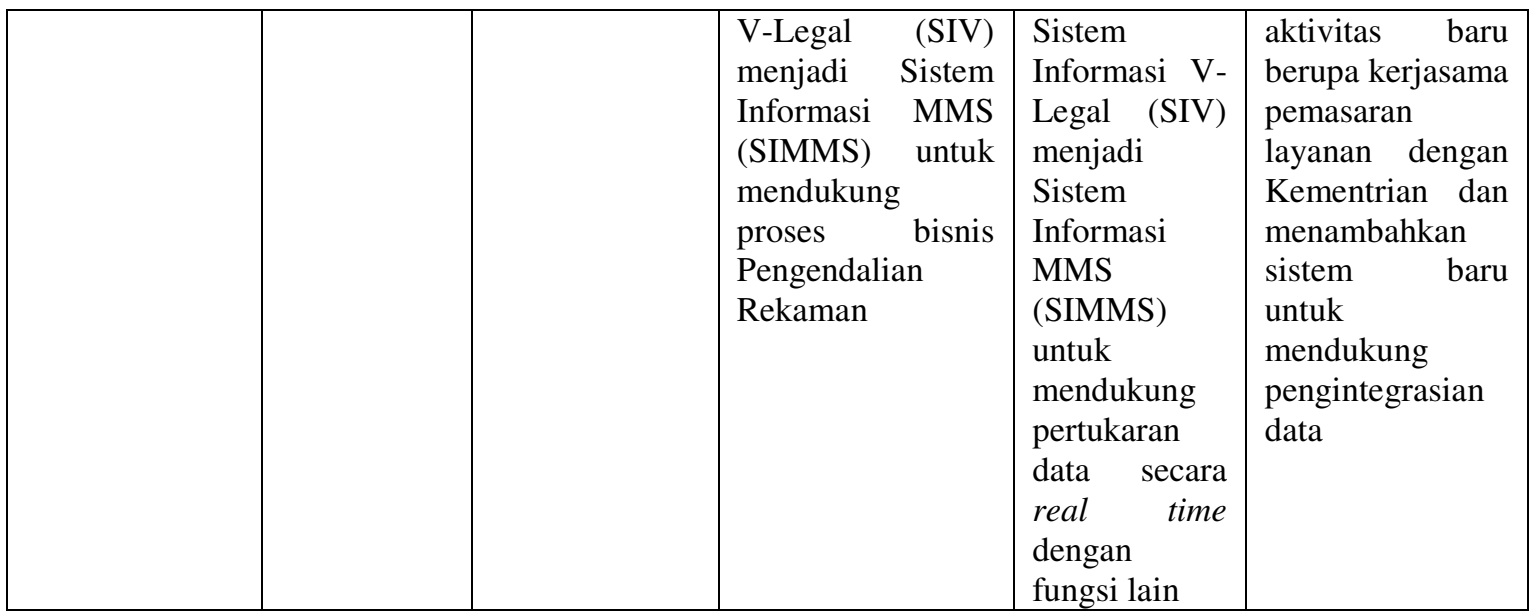

\subsection{Information System Architecture}

Fase ini dilakukan dengan beberapa cara yaitu Data Architecture dan Application Architecture.

\subsubsection{Data Architecture}

Pada fase ini dilakukan pengidentifikasian entitas data dan atribut yang dimiliki serta menggambarkan relasi nya diikuti keterangan relasi yang dimiliki. Aktifitas tersebut kemudian digambarkan kedalam conceptual data diagram dengan menggunakan Entity Relational Diagram (ERD). Kemudian enttas data tersebut digambarkan relasinya dengan layanan bisnis dan sistem yang digunakan PT XYZ kedalam data dissemination diagram. Berikut merupakan comceptual data diagram usulan dan data dissemination usulan untuk PT XYZ yang dapat dilihat pada Gambar 3 dan Gambar 4 dibawah ini.

Keterangan:

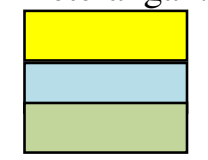

: Entitas target

: Entitas yang diambil dari aplikasi lain

: Entitas eksisting 


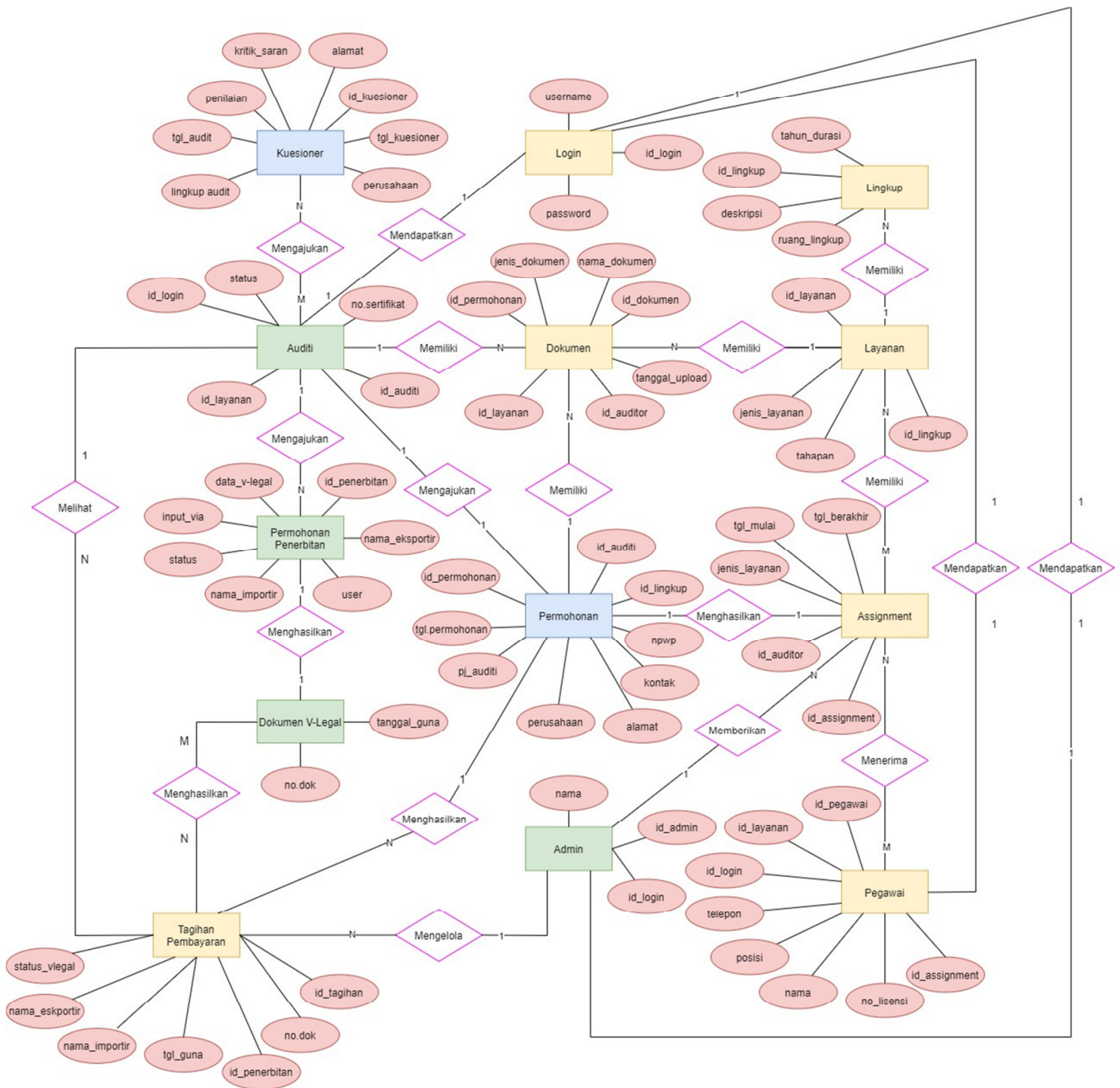

Gambar 3. Conceptual Data Diagram Aplikasi Target 


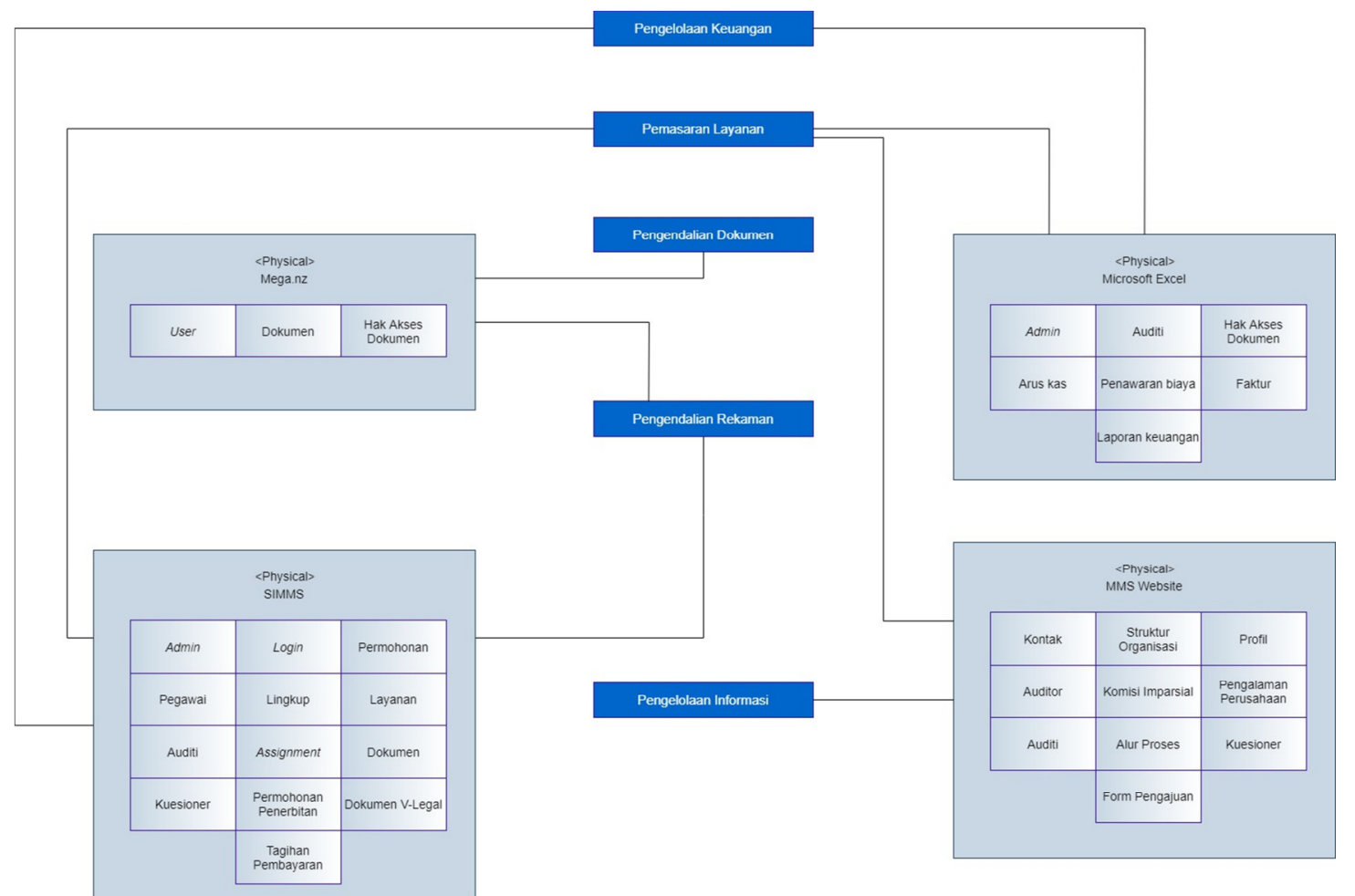

Gambar 4. Data Dissemination Diagram Target

\subsubsection{Application Architecture}

Pada fase ini dilakukan pemetaan hubungan antara aplikasi dengan fungsi bisnis yang ada di PT XYZ untuk mengetahui aplikasi apa saja yang mendukung fungsi bisnis di PT XYZ. Kemudian dilanjutkan pemetaan hubungan antara aplikasi dengan aplikasi lainnya untuk menjelaskan keterkaitan penggunaan aplikasi. Berikut dapat dilihat Tabel 4 Application / Function Matrix dan Gambar 5 Application Communication Diagram PT XYZ yang dihasilkan pada fase ini.

Keterangan:

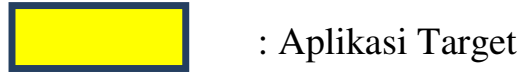

Tabel 4. Application / Function Matrix

\begin{tabular}{|c|c|c|c|c|c|c|}
\hline $\begin{array}{l}\text { Physical Application } \\
\text { / Business Function } \\
\text { Physical Application }\end{array}$ & 苞 & 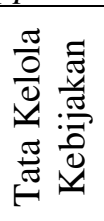 & 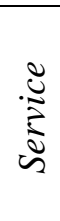 & 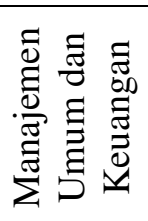 & 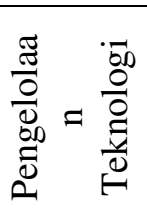 & 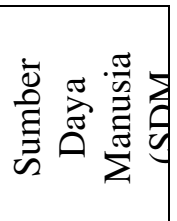 \\
\hline Microsoft Excel & - & - & - & $\mathrm{V}$ & - & V \\
\hline Microsoft Access & - & - & - & - & - & - \\
\hline Mega.nz & - & V & & $\mathrm{V}$ & V & V \\
\hline
\end{tabular}

Pramesti, ei., al [Enterprise Architecture Sebagai Optimalisasi Proses dan Pengembangan Teknologi Informasi Menggunakan Togaf ADM (Studi Kasus: PT XYZ) 


\begin{tabular}{|l|c|c|c|c|c|c|}
\hline MMS Website & - & V & - & V & V & - \\
\hline $\begin{array}{l}\text { Sistem Informasi } \\
\text { MMS (SIMMS) }\end{array}$ & V & V & V & V & V & - \\
\hline
\end{tabular}

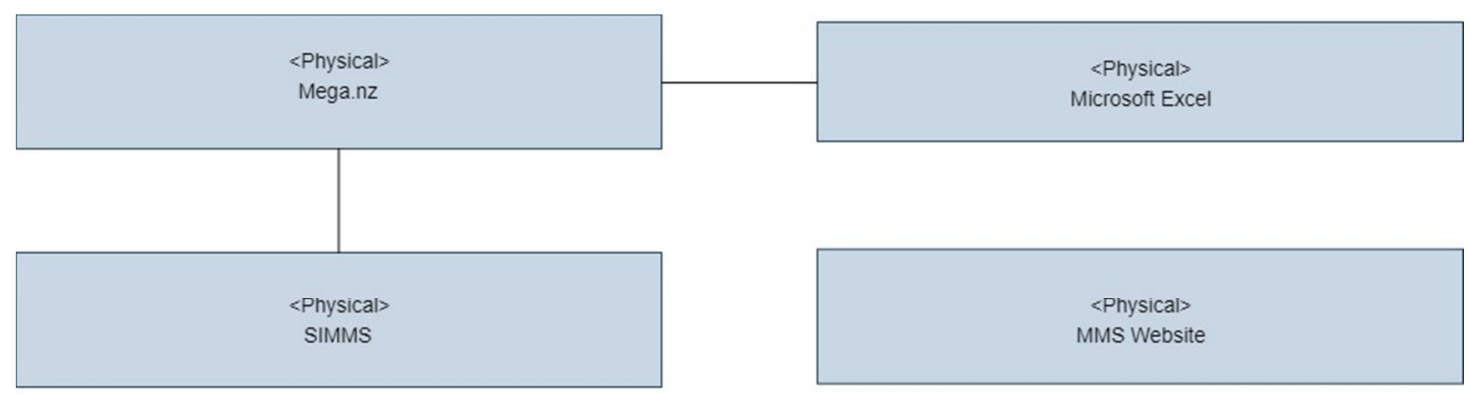

Gambar 5. Application Communication Diagram

\section{KESIMPULAN}

Penelitian ini berfokus pada perancangan Enterprise Architecture menggunakan metode TOGAF ADM untuk fungsi Manajemen Umum dan Keuangan pada PT XYZ. Tahap perancangan dimulai dari Preliminary Phase hingga Information System Architecture (Application Architecture), yang tiap fasenya menghasilkan matrices, catalog, dan diagram pada setiap domain bisnis, data, dan aplikasi. Pada analisis dan perancangan menghasilkan perancangan target (to be).

Dari hasil analisis bisnis terdapat perbaikan proses bisnis eksisting yaitu pada proses bisnis pengendalian rekaman, pengelolaan keuangan, dan pemasaran layanan. Proses pengendalian rekaman didukung oleh Sistem Informasi MMS sebagai media pengarsipan dokumen yang telah diunggah oleh klien, kemudian disusun menjadi sebuah rekaman dengan format yang disediakan. Proses pengelolaan keuangan juga didukung oleh Sistem Informasi MMS sebagai media untuk membuat tagihan pembayaran secara otomatisasi sesuai dengan permohonan penerbitan yang diajukan dan digunakan oleh klien. Untuk proses pemasaran layanan terdapat penambahan aktivitas baru yang juga didukung oleh Sistem Informasi MMS dan aplikasi eksisting lainnya.

Untuk menyesuaikan dengan target bisnis yang ada, maka dilakukan pengidentifikasian entitas dan atribut baru beserta relasi yang dimiliki untuk mendukung layanan fungsi Manajemen Umum dan Keuangan dan yang dibutuhkan untuk mendukung Sistem Informasi MMS. Selain itu, untuk aplikasi terdapat pengembangan Sistem Informasi V-Legal menjadi Sistem Informasi MMS (SIMMS) yang kemudian dipetakan kepada user yang menggunakan aplikasi tersebut dan pemetaan antar aplikasi yang berkaitan untuk memudahkan dalam memahami pertukaran data yang terjadi secara real time dan menghindari adanya duplikasi data.

Pada penelitian ini menghasilkan blueprint perancangan enterprise architecture, dimana berisi hasil analisis perancangan eksisting dan target fungsi Manajemen Umum dan Keuangan. Blueprint ini juga dapat dijadikan acuan dalam proses optimalisasi proses dan pengembangan Teknologi Informasi (TI) karena tetap menyesuaikan dengan requirement dan permasalahan yang terjadi pada fungsi Manajemen Umum dan Keuangan PT XYZ.

Pramesti, ei., al [Enterprise Architecture Sebagai Optimalisasi Proses dan Pengembangan Teknologi Informasi Menggunakan Togaf ADM (Studi Kasus: PT XYZ) 
Diharapkan dengan blueprint hasil dari perancangan EA ini, dapat menyelesaikan permasalahan pada proses yang tidak maksimal dan penggunaan aplikasi yang belum mendukung operasional bisnis perusahaan. Sehingga mendukung perusahaan dalam mewujudkan visinya menjadi lembaga sertifikasi yang handal, professional, bertanggung jawab, dan memberikan hasil berdaya guna dengan mengutamakan kepuasan pelanggan.

\section{DAFTAR PUSTAKA}

[1] I. N. Aulia, I. K. Raharjana, and Purbandini, 2017. "Perencanaan Arsitektur Perusahaan pada Bagian Instalasi Rawat Jalan dengan Kerangka Kerja TOGAF ADM," J. Inf. Syst. Eng. Bus. Intell., Vol. 3, No. 1, pp. 52-60,

[2] A. Supriatna, 2010 "Analisa Penerapan Togaf dan Cobit Dalam Tata Kelola Teknologi Informasi Sebagai Usulan pada Kementerian Energi dan Sumber Daya Mineral," Semin. Nas. Inform., Vol. 2010, No. semnasIF, pp. 1-8,.

[3] D. H. Olsen and K. Trelsgård, 2016, "Enterprise Architecture Adoption Challenges: An Exploratory Case Study of The Norwegian Higher Education Sector," Procedia Comput. Sci., vol. 100, no. 1877, pp. 804-811, doi: 10.1016/j.procs.2016.09.228.

[4] J. Prayoga, 2017. "Penerapan Teknologi Informasi Dalam Peningkatan Efektivitas, Efisiensi dan Produktivitas Perusahaan," Maj. Ilm. War. Dharmawangsa, Vol. 87, No. 1,2 , pp. 149-200,

[5] N. Syynimaa, 2015, "Modeling The Dynamics of Enterprise Architecture Adoption Process," Lect. Notes Bus. Inf. Process., Vol. 241, pp. 577-594, doi: 10.1007/978-3-31929133-8_28.

[6] S. A. Rumapea and B. Sitohang, 2018, "Quality Framework For Quality Assuring Enterprise Architecture Model," Proc. 2017 4th Int. Conf. Comput. Appl. Inf. Process. Technol. CAIPT 2017, Vol. 2018-Janua, pp. 1-5, doi: 10.1109/CAIPT.2017.8320740.

[7] R. Setiawan, 2016, "Perancangan Arsitektur Enterprise Untuk Perguruan Tinggi Swasta Menggunakan Togaf Adm," J. Algoritm., Vol. 12, No. 2, pp. 548-561, doi: 10.33364/algoritma/v.12-2.548.

[8] S. Rahayu and A. Hadiana, 2017, "Perancangan Enterprise Architecture Berbasis Service Menggunakan Zachman Framework: Studi Kasus PDAM Kota Sukabumi,” J. Teknol. Rekayasa, Vol. 1, No. 1, p. 59, doi: 10.31544/jtera.v1.i1.2016.59-66.

[9] Y. Dorohyi, V. Tsurkan, S. Telenyk, and O. Doroha-Ivaniuk, 2017, "A Comparison Enterprise Architecture Frameworks For Critical IT Infrastructure Design," Collect. "Information Technol. Secur., Vol. 5, No. 2, pp. 90-118, doi: 10.20535/24111031.2017.5.2.136976.

[10] D. Nana and H. Elin, 2018, "Memilih Metode Penelitian yang Tepat: Bagi Penelitian Bidang Ilmu Manajemen,” J. Ilmu Manaj., Vol. 5, No. 1, p. 288, [Online]. Available: https://jurnal.unigal.ac.id/index.php/ekonologi/article/view/1359. 
[11] C. Kearny, A. Gerber, and A. Van Der Merwe, 2017, "Data-Driven Enterprise Architecture and The TOGAF ADM Phases,” 2016 IEEE Int. Conf. Syst. Man, Cybern. SMC 2016 - Conf. Proc., pp. 4603-4608, doi: 10.1109/SMC.2016.7844957. 